\title{
Representations of the Family in Postwar British Amateur Film: Family Histories in the Lane and Scrutton Collection at the East Anglian Film Archive
}

\begin{abstract}
This article examines the construction of the postwar British family in amateur film with reference to the Sidney Lane and Cecil Scrutton collection held at the East Anglian Film Archive (EAFA), particularly the films covering 1948 - 1961.

Heather Norris Nicholson argues that home movies contribute to 'an understanding of leisure and visual-related practices of consumption as well as the social processes by which people came to give themselves, and others, identities' in the mid-twentieth century (Nicholson, 2004, p. 323).
\end{abstract}

By considering the social and historical contexts in which these home movies were produced, and using accompanying notes by one of the filmmaker's sons, the leisure time films of Lane and Scrutton can be analysed in order to understand how the amateur cine hobby ideologically constructed family, community and national identity in postwar Britain. The images of Christmas parties, daytrips and holidays in these films reveal much about this particular family, and are therefore very illuminating to the social historian and film scholar of today.

\section{Introduction}

This article examines the construction of the postwar British family in amateur film with reference to the Sidney Lane and Cecil Scrutton collection held at the East Anglian Film Archive (EAFA), particularly the films covering 1948 - 1961. This 
collection is noteworthy, not only for its substantial amount of film, but also because it covers a period that is identified by historians as significant in the ideological construction of the postwar family unit. Archival reminiscences by Richard Lane, the son of one of the filmmakers, also help to build a picture of this Norwich family from the late 1940 s to the early ' 60 s.

Lane and Scrutton were brothers-in-law who each owned news agency businesses and who shared a $9.5 \mathrm{~mm}$ camera that they bought in 1951 . The films made previous to this were shot on a camera belonging to another brother-in-law, Herbert Cross. These relationships tend to suggest that for the Lanes, Scruttons and Crosses, filmmaking was a family hobby, with the three fathers sharing equipment, and, in the case of Scrutton and Lane, also purchasing equipment together.

Nicholson discloses how home movies contribute to 'an understanding of leisure and visual-related practices of consumption as well as the social processes by which people came to give themselves, and others, identities' in the mid-twentieth century (Nicholson, 2004, p. 323). This is certainly evident in the Lane and Scrutton collection. The cine hobby and the family holiday offer a highly condensed interpretation of leisure, in which both the cultural practice of the holiday and its visual construction on film, reveal much about the self-representation of the families involved. Sidney Lane and Cecil Scrutton bought their cine equipment from Doughty's shop in the holiday resort of Great Yarmouth, which immediately equates their own film hobby with the family holidays that they took on the East Coast of the UK (Lane, 2006, p. 1).

Zimmermann points out that, rather than for public display, the home movie 'is a 
subset of the amateur film movement located within individual and/or familial practices of visual recording of intimate events and rituals and intended for private usage and exhibition' (Ishizuka and Zimmermann (eds.), 2008, p. 8). The Lane and Scrutton films arguably belong to a type of filmmaking that Shand refers to as the 'home mode', after Richard Chalfen. Shand says that 'the home mode is not a genre of amateur cultural production, but rather an exhibition space where self-produced materials are shown to the intended audience of family and close friends' (Shand, 2008, p. 39).

Importantly, for the Lanes and Scruttons, the films were not only a record of the family's leisure time, but rather, they were produced in order to entertain the onscreen participants during domestic film shows. Richard Lane explains, for instance that 'showing these films became an integral part of Christmas and other family parties held during the winter' (Lane, 2006, p. 1). This equates with the 'private projections' that Peixoto refers to 'in which the family members recognize themselves as fictional characters, remembering all the happenings (" $O$ h, that's how it happened...') and commenting on all scenes with emotion or remembrance' (Peixoto, 2008, p. 2).

Although I analyse these films to reveal how they help to construct an image of the family in postwar Britain, it is important to consider that the Lane and Scrutton films may not be representative of all families in this place and time, nor indeed might they be representative of the day-to-day lives of the people on screen. Instead, they are a selective construction of this extended family's leisure time: parties in the home, playtimes in the garden, daytrips, and holidays. As Shand argues, the 'selective representations' in home movies 'are not intentionally misleading; they merely 
perform the specific social function of projecting an idealized image back onto the participants' (Shand, 2008, p. 40). This 'idealized image' may partly have been a way for the Lanes and Scruttons to reaffirm their sense of family, community, and national identity after the horrors of the Second World War.

This article will therefore reveal how this particular Norwich family chose to represent their lives and leisure in postwar Britain, in the home, and during holidays around Norfolk, and other parts of the UK.

\section{Norwich at war}

In the early 1940s, Norwich was one of the targets of the Baedeker raids that aimed to destroy areas of British cultural and historical interest (Bowman, 2012, p. 10, and Snelling, 2013, p. 16). Many of the bombs fell in residential streets to the West of the city centre where the Lane and Scrutton families lived. Snelling, for instance reports that houses were destroyed on Elizabeth Fry Road and The Avenues, near to Colman Road where Lane's newsagent shop stood, and that there was much bomb damage to streets off Dereham Road (Snelling, 2013, pp. 34 - 40, and pp. 71 - 2).

Although the Scruttons lived further out west on Dereham Road, the bomb-damaged streets would have been familiar from the news rounds they owned in the nearby Larkman and West Earlham areas. Earlham cemetery became the resting place for a 'hundred or so people' who were buried there 'over two days in May 1942' (Snelling, 2013, p. 157). Similarly, Eaton Park where baby Richard Lane is first filmed in 1948, was temporarily used as a morgue six years earlier, in the aftermath of the air raids (Snelling, 2013, p. 89). 
The Ministry of Home Security recorded that 14,000 houses were damaged, 1,200 of these being 'wrecked', and that 20 factories were destroyed or seriously damaged by bombs (Bowman, 2012, p. 23). Nevertheless, 'milkmen, postmen, and papermen' continued to make deliveries around the city, as one thankful Eastern Daily Press reader commented after a particularly heavy raid in April 1942 (Snelling, 2013, p. 104). Snelling recalls that as he grew up in postwar Norwich, he eventually realised that 'the scars and wounds of that terrible and terrifying experience were still visible in the disfigured terraces and hurried post-war reconstruction' (Snelling, 2013, p. 5). However, this type of landscape is not visible in the Lane and Scrutton films. Instead, the Norwich streets and surrounding county where the family play, ideologically reconstruct postwar Britain as an idyll of leisure.

The only scenes of devastation in this family's collection are a record of the Norfolk floods of 1953 - a natural disaster which claimed many lives. Richard Lane's notes refer to the 'Floods Aftermath' footage as being shot at Walcott, Great Yarmouth, Lowestoft, Cley, Salthouse, and Wells, where a boat is 'stranded on the quay' (Lane, 2006, p. 12). Such footage is rare in this collection, however, and its strange position somewhere between the tourist gaze and reportage seems strangely incongruous in these home movies.

\section{Postwar Britain}

Laing argues that the Coronation of Elizabeth II in the summer of 1953 signaled a change from wartime austerity to postwar affluence. This was memorably expressed by the huge increase in the purchase of television sets, so that families could watch the national event at home (Laing, 1986, p. 9). Gurney points out that in 1950 'only 
about 1 percent of the population of the United Kingdom owned a television' but by 1965, 'this figure had reached almost 25 percent' (Gurney, 2005, p. 957). The period between 1952 - 1954 also saw the end of rationing and a broadening of the middle classes with 'patterns of consumption as decisive indicators' that working-class people had adopted middle-class luxuries, 'such as television sets, cars and annual holidays' (Laing citing Crosland, 1986, p. 16). Consumer spending was largely helped by hire purchase, with credit trade 'increasing from $£ 2.6$ million in 1946 to $£ 18.8$ million in 1958' (Gurney, 2005, p. 976).

This postwar context, and the owning their small business allowed the Lanes and Scruttons to adopt their middle class lifestyle through consumer spending, of which the cine hobby, car ownership and regular holidays were combined. The sharing of their cine equipment meant that not only could these families divide the costs of this potentially expensive hobby, but also that most of the activities captured on camera are constructed as part of an extended family group.

Lury points out that as 'cameras and film stock were expensive in pre- and postwar periods, [home movies] were generally made by wealthy, middle-class men such as medical doctors and directors of small businesses' (Lury, 2013, p. 268). The Lanes and Scruttons are perhaps not as wealthy as the households mentioned by Lury, nor do their films portray a level of wealth seen in some home movies from the interwar years such as the Burne family collection as Screen Archive South East and the Unwin family collection at EAFA. ${ }^{1}$ These families had servants and holiday homes where most of their amateur films were shot. Instead, the Lanes and Scruttons might be considered as typical of the broadening of the middle classes in the postwar period. 
Regular holidays were still relatively rare amongst the working classes in the first few years following the Second World War, and therefore the frequent excursions by the Lanes and Scruttons in their Morris Minors points towards a lower middle class social mobility. The postwar diary of Mass Observer, Herbert Brush, for instance, records a similar type of motoring holiday from London to Cornwall in 1945 where he finds Italian Prisoners of War dismantling an anti-invasion fence at Porthluney Cove (Garfield, 2005, p.62). Such opportunities for holidaying were scarce immediately after the war, however, and most British families were content to ease themselves into the holiday spirit with the occasional daytrip. Kynaston, for instance, suggests that:

Day trips mattered, given that the nationwide Social Survey found in 1949 not only that almost half the adult population had not had a holiday away from home that year but also that for those who had not holidayed, just over half had had day trips instead... [and that] holiday-making was far more frequent among the better-off and those in urban occupations with a tradition of paid holidays (Kynaston, 2010, p. 212).

The postwar holidays that Kynaston describes are often of the 'bucket-and-spade' variety with packed trains and 'fully booked' motor coaches (Kynaston, 2010, p. 497). However, he does refer to a more sedate Bank Holiday trip in the mid-1950s taken by the Haines family to Chelmsford, including a picnic en route to see Essex play Worcestershire at cricket, and a stop off on the way home to buy fish and chips at Epping (Kynaston, 2010, p. 498). This tends to mirror the types of excursions that are seen in the Lane and Scrutton films of the late 1940s and early ' 50 s. 
Richard Lane points out that those who were privileged enough to enjoy these postwar motoring holidays, often did not have to book accommodation in advance. Instead, he says, 'Sidney just decided which part of the country we were to visit and set off in the car. When he found a suitable hotel, usually a Trust House, he just booked in for one or more nights' (Lane, 2006, p. 13). He also reveals that the touring caravan that appears in their films from 1958 was also bought between the two families - another indication of the way that they budgeted for their leisure time. The shared caravan also resulted in more of the communal holidays that are constructed in the films (Lane, 2006, p. 16).

\section{The construction of the family and the cine hobby}

According to Tincknell, 'In the immediate period after the Second World War, from 1945 until the early 1950s, in the UK, the USA and much of Western Europe, the family was regarded as a central cornerstone in the necessary physical and ideological reconstruction of civil society' (Tincknell, 2005, p. 6). Similarly Chambers, says that 'the modern 'functional' family ... reached its peak around the 1950s, during which the white, middle-class, patriarchal, 'nuclear' version of the family emerged as the dominant model' (Chambers, 2001, p. 49).

If the nuclear family was ideologically constructed in conjunction with postwar consumption, then it appears that the amateur cine hobby played a part in this selfperpetuating image. Smith points out that towards the latter part of the twentieth century, the free time provided by lower birth cohorts was reflected in the 'increased potential for consumption and leisure pursuits' (Richard M. Smith in Obelkevich and Catterall, eds. 1994, 26). However, this pattern of smaller families and increased 
leisure time is arguably already evident in the postwar films of Lane and Scrutton, who have only two and three children, respectively. The leisure activities of the two families makes up for these small cohorts by extending to include in-laws and cousins, which gives the viewer an impression of a large family group with strong ties.

Although Lury says that amateur films are often 'informed by a patriarchal gaze' (Lury, 2013, p. 268), there is evidence of contemporary instructional material for hobbyists that suggests both parents take turn to operate the camera (Alder, 1950, pp. $110-112$, and Wain, 1962, p. 7). This is reiterated by Nicholson who argues that:

Narratives of family outings and holidays were not exclusively shaped by men. Opportunities to step aside from childcare and other gendered conventions of domesticity occurred more readily for women when they were away from home (Nicholson, 2012, p. 199).

Women were often foregrounded in cine equipment advertising, which ideologically constructs their position as hobbyists. For example, the woman demonstrating 'selferecting screens' in the Actina photographic shop advert from 1945 (ACW, p. 324), and the woman holding an Ampro sound projector in the Saville of York advert from 1951 ( $A C W$, inside front cover).

It could be argued that although Sidney Lane and Cecil Scrutton are often in control of the camera, the subject matter of their family films usually foregrounds the children, and in this respect it is they, however unintentionally, who call the shots. The family holidays, children's parties, and cine apparatus may be paid for by the 
fathers' businesses, but traditionally, these are leisure activities in which women and children take centre stage, and the men of the household are sidelined to a certain extent. It is therefore often left to the father to pick up the camera and capture the family antics on film.

On the occasions where Sidney Lane and Cecil Scrutton are captured on camerapresumably by each other, or by their partners - they subvert the idea of paternal authority by fooling around. For example, pulling faces in close-up at a Christmas party, or dressing in drag on the beach, which I will return to later. As such, the Lanes and Scruttons operate as 'personalized' families, in which 'children have greater control over the decision-making, and boundary maintenance within the home is less of a concern' (Lury, 2013, p. 281). There is a relaxed quality to these films, therefore, which paints a picture of a family with a great sense of fun and genuine affection for each other, and which warms the present-day viewer to their frolics. Scholars of memory studies such as Holland (1991) and Kuhn (2002), do not always communicate this palpable sense of pleasure in their work on family photography, which may be something of an oversight.

Shand argues that 'family films' can be either fiction or nonfiction. Strictly speaking, Shand might refer to the Lane and Scrutton films as 'films of families' rather than of the 'family film' genre, yet they also inhabit a middle ground between these two styles because although the members of the family appear as themselves in private, non-narrative home movies, the resultant films belie an awareness of classical filmmaking techniques (Shand, 2015, p. 21). This make them appear semi-planned, and gives them a greater aesthetic value than some of the 'baby on the lawn' films 
that appear often in many cine collections, as I will explain below (Alder, 1950, p. 109).

\section{The Sidney Lane and Cecil Scrutton film collection}

In order to understand how a family represents itself on film, it can be useful for the film historian to examine a family collection in its entirety, rather than to view individual films in isolation. This provides a fuller picture of the family's selfrepresentation over time, and an idea of favoured subject matters and places of interest. If the collection has accompanying notes made by one of the family members, these can offer useful contextual material about the family's social class, their professions, the cine equipment that they purchased, and about how the screening of the films played a part in family gatherings. The notes provided by Sidney Lane's son, Richard are a very good example of this.

The collection consists of 30 reels of film shot between 1941 and 1961, with the majority of the filming increasing from 1948. Each reel consists of a compilation of scenes including children at play, family parties, day trips and holidays. Most of the films are in $9.5 \mathrm{~mm}$ black and white but there are some rare scenes in colour. Each compilation may be taken as a review of family activities over the period of a few months. Most of the footage is attributed to either Lane or Scrutton, although there are some holiday films shot by their brother-in-law Herbert Cross on the Norfolk Broads and the South of France, for instance. The films on each reel are not all organized in chronological order, but Richard Lane identifies the years of production from notes and recollections made by his father, Sidney. 
It was possibly the arrival of his son, Richard that convinced Sidney Lane to purchase his own cine equipment, rather than continue to borrow Herbert Cross' camera.

Richard is often the focus of attention in the films which chart his early childhood. Alder (1950), Natkin (1955) and Wain's (1962) work advises hobbyists to construct narratives around films of babies and young children in order to maintain viewer interest. Lane eschews this type of highly-constructed scenario, and instead, an early appearance of Richard filmed in his pram at Eaton Park, Norwich (1948), is simply recorded in one long take.

The shot is held for a very long time, presumably to capture the expressions on the baby's face. This piece of portraiture is not rushed, and the cameraperson does not attempt to 'create' interest by unnecessarily moving the camera about. The intently held long take of Richard appears to reveal a deep fascination with Sidney Lane's first son, and demonstrates the man's paternal pride. When Richard Lane's brother, Peter is born in 1956 many of the following films prioritise him as the main subject. Peter's first appearance is in a big close-up, and subsequent films show his first holidays at Southport and Hopton-on-Sea $(1957,1958)$.

\section{Domestic space, the garden, and the family}

Richard Lane's notes hint at his family's devotion to the cine hobby. He reveals that Sidney Lane and Cecil Scrutton not only bought a camera and projector, but also a Haynorette Cine Editor, a Weston Master Cine Exposure Meter, and 'a set of freestanding floodlights which accounts for the quality of the indoor shots' (Lane, 2006, p. 1). They also bought a titling set and Scrutton constructed a frame to help position 
the camera correctly for filming close-up portraits.

This suggests that the films were not shot in total spontaneity, but were carefully constructed to a certain point with the use of titling, editing, and lighting, which allowed them to film indoors. Domestic interiors are relatively rare in family collections in comparison to outdoor holiday scenes, largely because of the need for extra lighting, which only the more serious or affluent filmmaker would stretch their budget to include.

The majority of the indoor scenes are films of Christmas gatherings and children's parties. These are occasions where several members of the extended family would be present, and therefore an ideal opportunity to capture everyone on camera for screening at subsequent parties.

The use of titles and intertitles give the historian clues about the family's sense of humour. For example, a Christmas 1951 film includes an intertitle that reads: 'Funny Faces. Any resemblance to a person or persons alive or dead is purely coincidental'. Richard Lane explains that "in some of the early 1950s reels, time was spent in captioning each sequence' and that the 'cartoons and free-hand lettering were done by Cecil'. For Scrutton, titling was an essential part of the family hobby, as Lane says:

In those days there was no television so a hobby such as cinematography would fill those vacant moments. You can see over the years how less and less time was spent on the films as titling became non-existent (Lane, 2006, p.1). 
The Christmas 1951 film features close-ups of the family members grimacing at the camera, much like the 'facials' of early cinema. Sidney Lane grotesquely pops his front false tooth out in one shot, and wears a cat mask in another. The specially built frame that Cecil Scrutton devised was utilized for these shots 'so that in close up, the faces could be lined up reasonably accurately with the lens rather than the viewfinder' (Lane, 2006, p. 9).

In 1952 Richard Lane and Steven Scrutton each have 'children's Christmas parties' (Lane, 2006, pp. 9 - 10). Holding two parties with all generations of the family present, again suggests a reasonable level of disposable income. Although some of the interior shots are a bit dark, a television can be seen in the living room of the Scrutton house one year before many families bought them in time for Queen Elizabeth II's Coronation, as mentioned previously. We might assume from Richard Lane's recollection that the purchase of the television resulted in the diminishing use of titling in the home movies.

The Lane and Scrutton films demonstrate that the filmmakers were aware of classical filmmaking techniques, and many of their films include sequences that incorporate long shots, mid shots and close-ups similar to the shots suggested in Alder's Family Movies Outdoors (1950). When the camera is not on a tripod, an attempt is made to at least keep the camera steady. The filmmakers also appear to favour close-ups and medium close-ups which help the audience to relate to the people in the films.

It is interesting to note, for instance, the care and skill with which Lane and Scrutton have shot and edited a short film of Steven Scrutton and Richard Lane (both aged 
between 6 and 8 ) having tea in the back garden of Cecil Scrutton's home at 86 Dereham Road, Norwich, during a sunny day in 1954. The viewer cannot be certain if either Sidney Lane or Cecil Scrutton shot the film because the subjects are the sons of each filmmaker, but it is possibly by Scrutton as it is filmed in his garden. The mother of one of the boys enters the sequence at one point with a kettle of water to refresh the teapot, so we may presume that Sybil Scrutton (nee Lane) is not the person behind the camera.

Whoever has filmed this short sequence, however, demonstrates that they have a proficient awareness of different shot sizes and camera angles. The tea scene is filmed from side view in long shot, then from an upstairs window of the house in extreme long shot, then in a close-up at the table where we cannot see details of the food, but the label of an HP Sauce bottle is visible. There then follows a mid-shot of Steven, a shot of both Steven and Richard filmed from behind Steven at a low angle, and then another long shot of the scene.

The two subjects are aware of being filmed. The construction of the scene with different camera angles has made the filmmaker's techniques conspicuous to the boys, and they frown quizzically back at the lens. In some respects, the cameraperson's (and subsequently the audience's) fascination with the scene feels like an invasion of the children's leisure space - perhaps akin to the spectacle of a chimp's tea party.

However, the scene is very civilized, and rather sophisticated for a children's tea, constructing an idyllic picture of the childhood home. A title used for another film in 
the same location as the tea scene refers to 'a happy scene in Steven's garden', which tends to suggest that the Scrutton family's back garden was their son's domain. This film from 1950 includes shots of the children playing on a slide and swing. Not all families of this era would have been able to afford a slide and swing, and it demonstrates that this postwar British garden had now become a space of leisure and play, rather than a place to grow vegetables or keep poultry as part of the war effort, for instance. A shed made from an Anderson shelter in the next door neighbour's garden stands as a reminder of the war.

\section{Local space: streets and play}

The streets outside the Lane and Scrutton houses do not appear often in the films, but when they do, they too are the domains of the younger members of the family. An early film in the collection shows Richard in 1950 riding on a small bike with stabilisers and then on a Mobo horse outside the shop on Colman Road. A winter scene on the same reel (reel 1) shows a group of boys playing with a go-kart on Colman Road. They are wearing winter coats, hats and scarves, but some of them are still wearing shorts with long socks, as was the fashion for children in this era. The roads are relatively quiet but there are some cars in the background and occasionally a bus goes by. A boy identified as Michael Robinson pushes Richard Lane around in a go-kart, and they both play with a small glider plane; the kind that would be built from a small kit.

With their newsagent shops and newspaper rounds in the suburbs of Norwich, the Lanes and Scruttons would have undoubtedly been known to members of the community on Colman Road and around the Larkman and West Earlham areas of 
Norwich. These films shot outside the shop tend to reaffirm the family's position as central figures of the community, with neighbouring children joining Richard Lane and Steven and David Scrutton during play.

These shots are reminiscent of the street photographs discussed by Thompson who argues that these images compel us 'to recognize a simple social fact: children used to occupy the streets of our cities. For all the important caveats about needing to read these images critically, this central fact is difficult either to dispute or not to be in some way moved by' (Thomson, 2013, p. $20-21$ ). The scrubland that the Lane and Scrutton children are sometimes filmed on near Dereham Road is revealed in Richard Lane's notes to be a building site slowly being developed for postwar housing:

It was always left open to public access and was a splendid play area for the local children. Piles of bricks became forts. Heaps of aggregates became battlegrounds for cowboys and old oil drums became extra fielders in cricket matches. If you hit one while batting you were out (Lane, 2006, p. 21).

The family were aware of popular film culture, and the 1951 footage of children recreating a hostage round-up in the style of an American Western brings out the humour of the filmmakers. Entitled 'Round Up!! Hoppalong Steve at work (Costume by Lanes)', this is a short sequence of Steven Scrutton in a cowboy costume pointing a gun at two boys and a girl. One of the boy captives' hands shake in mock fear.

In a couple of 1954 films Richard Lane dresses as a Mountie, sometimes to play with cowboys and a miniature pony on land behind the houses. He reflects on this in the accompanying notes: 
Apart from the famous musical film Rose Marie [1954], there had been one or two other films about the Mounties; Canadian Westerns really where the good guys always wore red. Hence our desire to have the uniform. They were bought from Hamley's in London (Lane, 2006, p. 21 - 22).

The reference to Hamley's demonstrates the family's middle class status. This Regent Street shop being a large department store entirely devoted to children's toys.

\section{Holidays and daytrips: the family and national identity}

An early holiday at Walcott, Norfolk, in 1949 points to the family's class status, because they are staying in a hired bungalow. As mentioned previously, the Lane and Scrutton families each owned a car, which was still a relatively rare commodity in postwar Britain, but which provided the filmmakers with a means to reach the seaside and tourist locations that featured heavily in their films. Their Morris Minors appear frequently in the cine film collection, sometimes as a backdrop to picnics. Lane and Scrutton's touring caravan also appears in some of the holiday films shot at Hoptonon-Sea in 1958.

As Annette Kuhn asserts about photography, '[t]he nuclear unit of the second half of the twentieth century is more likely to be travelling together as tourists, sampling other local histories, than it is to be a 'genuine' product of its current home locality' and this is the picture of family life that is mostly represented in the Lane and Scrutton collection (Kuhn in Spence and Holland, (Eds.), 1991, p. 104). 
The films of the daytrips and holidays help to construct the family's place within the British landscape. As evidenced by the film collection, the Lanes and Scruttons made numerous excursions between the late 1940s and early 1960s. On many of these trips, not only the nuclear family are present, but also members of the extended family, and there are frequent films where two carloads of people can be seen picnicking by the families' Morris Minors, walking in formal gardens, or frolicking on the beach.

National events and British landmarks that are represented in these films include The Festival of Britain (1951), London during the Coronation (1953) and a visit to Stonehenge, filmed in 1953 when visitors were still permitted to walk up close to the prehistoric stones. British history is constructed in these films as ancient (stone circles), heraldic (castles), quaint (cottages), and picturesque (landscapes). Tourism as spectacle is emphasised by road signs and signage at resorts that point out 'The Smallest house in Great Britain' or 'Highest Station in Great Britain'. These spots are considered as important places to record and construct a 'tourist gaze' picture of Britain by the amateur filmmaker (Urry, 2002, p. 78).

Many of the family's outings are filmed on the Norfolk coast, mostly at the less raucous, and therefore more middle class resorts such as Hemsby and Gorleston, although there are some trips to Great Yarmouth, which was - and still is - Norfolk's answer to Blackpool, and a resort more usually frequented by working-class holidaymakers. These resorts on the east coast would not have taken long for the Lanes and Scruttons to reach, but there are films in which the families make journeys that are slightly further afield. Reel 20, 1954, includes footage of a daytrip to Oakham in Rutland, which Richard Lane acknowledges was a 'long way to go for a day out 
especially with the roads as they were in the 1950s' (Lane, 2006, p. 21).

It is interesting to note how the family conducts themselves on camera, depending on the types of environment that they are situated in. In the more sedate setting of Holkham Hall, Norfolk (1951), the family members walk respectfully in the grounds of the stately home, framed against the architecture and formal gardens. In contrast to this, the seaside holiday invites more boisterous behaviour. During a road trip to Gorleston in 1951, adolescent David Scrutton sticks his tongue out at the camera, and in a family picnic scene at Felixtowe in the same year he gestures a ' $\mathrm{V}$ ' sign, presumably because he does not want to be filmed.

In summer 1951 an unidentified man (who could be Sidney Lane) lets his hair down by borrowing a woman's long skirt as she goes into the sea in her bathing costume. He walks along the sand with his arm campily linked in David Scrutton's, and swings a handbag. This act of transgression must have gone down well in family screenings, because in a subsequent family holiday in Wells (1952) it is David's turn to drag up on the beach, again wearing borrowed clothes or towels to make up a feminine costume.

As Inglis (2000) and Shields (2002) suggest, the seaside holiday is traditionally recognized as being a space and occasion that permits transgressive behaviour, and the presence of the cine camera during the Lane and Scrutton holidays appears to encourage the family to perform in this comical and unruly way.

The many visits to British landmarks construct the Lanes and Scruttons as affluent they are middle class and can afford these excursions, and the way these tourist spots 
and landscapes are represented in the films tends to affirm or reaffirm their sense of British identity in the postwar period. The sense of family identity is also reinforced by these extended family holidays because, as I mentioned previously, quite often these trips do not just include a nuclear family of four, but rather two carloads of people from both the Lane and Scrutton families.

\section{Conclusion}

The home movies of Sidney Lane and Cecil Scrutton construct a picture of a postwar nation not only at ease with itself, but perhaps deliberately setting out to reconstruct their own image of the family, of Norwich, and of Britain, through their cine hobby and their leisure time. These families may not have been relatively typical of all British families of the late 1940s and early '50s, but appear to have been typical of the white middle class cine hobbyists who could afford camera equipment, motor cars, and regular daytrips and holidays.

The films of children at play in their homes and gardens, and in the neighbouring streets and parks in Norfolk all construct a strong sense of familial harmony, and of domestic and local space. This feeling radiates further afield during daytrips and holidays, where the Lanes and Scruttons enjoy visiting British coastal resorts and national tourist locations, something which can be summarized by Kuhn's assertion that a 'desire for union [and] wholeness' is found in shared memories of family, home and nation (Kuhn, 2002, p. 169).

The Lane and Scrutton collection may not offer a full representation of these particular families - but they do reveal some aspects of the family's leisure times and 
the events that the filmmakers considered significant enough to capture on film. They also reveal which members of the family most frequently appeared as the subjects of the films, and therefore perhaps, who was most often behind the camera. Although Sidney Lane and Cecil Scrutton seldom appear in their own films, their roles as filmmakers and projectionists can be analysed in Nicholson's terms as a form of 'autobiography':

While the filmmaker may be out of sight for much of a film's running time, typically appearing only in occasional - and loosely staged - walk-on parts, subsequent screening usually involves greater prominence, as all-in-one narrator, presenter and projectionist (Nicholson in Craven, (Ed.), 2009, p. 96).

This is the type of role that Lane and Scrutton would have adopted during the subsequent Christmas screenings recalled in the notes by Richard Lane.

EAFA acquisitions officer Louise Lawrence says that, 'there is an intimacy in the moving image [that] brings things to life in a way nothing else can' (quoted in BartonWood, 2014, p. 136). As the researcher looks through the years of holidays and parties in the Lane and Scrutton archive, he or she may warm to the personalities on screen and become accustomed to the family's favourite haunts, their quirks, and their sense of humour. In this case, the Lane and Scrutton films enable the family to construct their identities through leisure and consumption, perhaps as a reaction to the horrors of war. As Nicholson argues, 
Family films occur within specific socio-economic, political and cultural contexts. They are selective in their choice of particular places, memorable moments and family members. They map out the spatial geometries and micropolitics of family life... They become the stories people like to tell, show and share about themselves (Nicholson, 2001, p. 130).

The films of Lane and Scrutton therefore construct a warm and humourous narrative of family, region and nation in the postwar era that is illuminating to the social historian and film scholar of today.

\section{References}

Amateur Cine World, December 1945 - February 1946, Actina advertisement, 324. Amateur Cine World, September 1951, Ampro advertisement, inside front cover. Amateur Cine World, September 1951, Celfix advertisement, 413.

Alder, R. H. (1950). Family Movies Outdoors, London: Fountain Press.

Barton-Wood, S. (2014). Through Fire and Flood, Saving Norfolk's Archives, Norfolk: Poppyland Publishing.

Bowman, M, (2012). Images of War, Norwich Blitz, Rare Photographs from Wartime Archives, Barnsley: Pen and Sword Military.

Chamber, D. (2001). Representing the Family, London: Sage.

Craven, I. (Ed.). (2009). Movies on Home Ground: Explorations in Amateur Cinema, Newcastle: Cambridge Scholars Publishing.

Garfield, S. (2005). Our Hidden Lives, the Remarkable Diaries of Post-war Britain, London: Ebury Press.

Gurney, P. (2005). 'The Battle of the Consumer in Postwar Britain', The Journal of Modern History, Vol. 77, No. 4, 956 - 987.

Inglis, F. (2000). The Delicious History of the Holiday, London: Routledge. 
Ishizuka, K. L. \& Zimmermann, P. R. (Eds.). (2008). Mining the Home Movie, London: University of California Press.

Kuhn, A. (2002). Family Secrets, Acts of Memory and Imagination, London: Verso.

Kynaston, D. (2010). Family Britain, 1951 - 1957 (Tales of a New Jerusalem), London: Bloomsbury.

Laing, S. (1986). Representations of Working-Class Life 1957-1964, London: Macmillan.

Lury, K. (2013). 'Halfway Down the Stairs', Home Cultures, 10:3, 267 - 286.

Lane, R. (2006). Accompanying notes for the Sidney Lane and Cecil Scrutton Collection, East Anglia Film Archive.

Natkin, M. (1955). How To Film Children, London: Fountain Press.

Nicholson, H. N. (2001). 'Seeing how it was?: Childhood Geographies and Memories in Home Movies, Area, 33.2, 128 - 140.

Nicholson, H. N. (2004). 'At Home and Abroad with Cine Enthusiasts: Regional Amateur Filmmaking and Visualizing the Mediterranean, ca. 1928 - 1962', Geojournal 49, 323 - 333.

Nicholson, H. N. (2012). Amateur Film, Meaning and Practice 1927 - 77, Manchester: Manchester University Press.

Obelkevich, J. \& C. P. (Eds.). (1994). Understanding Post-war British Society, London: Routledge.

Peixoto, C. E. (2008). 'Family Film: From Family Registers to Historical Artifacts', Visual Anthropology, 21, 1-12.

Shand, R. (2008). 'Theorizing Amateur Cinema, Limitations and Possibilities', The Moving Image: The Journal of the Association of Moving Image Archivists and Film History, Vol. 8, No. 2, 36-60.

Shand, R. (2015). 'The "Family Film" as Amateur Production Genre, Frank Marshall's Comic Narratives', The Moving Image: The Journal of the Association of Moving Image Archivists and Film History, Vol. 15, No. 2, 1 - 27.

Shields, R. (2002). Places on the Margin, Alternative Geographies of Modernity, London: Routledge.

Snelling, S. (2013). Norwich a Shattered City, the Story of Hitler's Blitz on Norwich and its People 1942, Somerset: Halsgrove.

Spence, J. \& Holland, P. (Eds.). (1991). Family Snaps, The Meanings of Domestic Photography, London: Virago Press. 
Thomson, M. (2013). Lost Freedom, The Landscape of the Child and the British PostWar Settlement, Oxford: Oxford University Press.

Tincknell, E. (2005). Mediating the Family, Gender, Culture and Representation, London: Hodder Arnold.

Urry, J. (2002). The Tourist Gaze, London: Sage.

Wain, G. (1962). Filming the Family, London: Fountain Press.

\section{Notes}

${ }^{1}$ Summer Seaside Holiday and Family Scenes, March - October 1929, Screen Archive South East, and Unwin Family Films 1, 1936 - 1938 Cat. no. 800, EAFA. 